\title{
Feedlot performance, feeding behavior and rumen morphometrics of Nellore cattle submitted to different feeding frequencies
}

\author{
Juliana da Silva ${ }^{1}$, Tássia Veluma Barbosa Carrara ${ }^{3}$, Murillo Ceola Stefano Pereira ${ }^{3}$, Cassiele Aparecida de Oliveira ${ }^{1}$, Ivan Carlos Batista \\ Júnior $^{2}$, Daniel Hideki Mariano Watanabe², André Luiz Nagatani Rigueiro³, Mário De Beni Arrigoni³, Danilo Domingues Millen²*
}

\begin{abstract}
IUniversity of São Paulo/FZEA - Dept. of Animal Science, Av. Duque de Caxias Norte, 225 - 13635-900 - Pirassununga, SP - Brazil.

${ }^{2}$ São Paulo State University/FCAT, Rod. Cmte João Ribeiro de Barros, km 651 - 17900-000 - Dracena, SP - Brazil.

${ }^{3}$ São Paulo State University/FMVZ - Dept. of Animal Breeding and Nutrition, R. Prof. Dr. Walter Mauricio Correa, $\mathrm{s} / \mathrm{n}-$

18618-681 - Botucatu, SP - Brazil.

*Corresponding author < danilomillen@dracena.unesp.br>
\end{abstract}

Edited by: Gerson Barreto Mourão

Received August 25, 2016

Accepted February 02, 2017
ABSTRACT: Owing to the lack of information in the literature about the ideal feeding frequency adopted by feedlot systems, this study was designed to evaluate the effect of different feeding frequencies on performance, carcass traits, feeding behavior and rumen morphometrics of Nellore cattle. Forty-eight yearling bulls were housed in individual pens with an average initial body weight of $358.2 \mathrm{~kg}$. The experiment was designed as a completely randomized block and the treatments were the feeding of cattle one, two, three, or four times daily ( $n=12$ per treatment). Orthogonal contrasts were used to assess linear, quadratic and cubic relationship between feeding frequency and the dependent variable. As feeding frequency increased, final body weight ( $p=0.03$ ) and average daily gain ( $p=0.01$; one: $0.98 \mathrm{~kg} \mathrm{~d}^{-1}$; two: $0.96 \mathrm{~kg} \mathrm{~d}^{-1}$; three: 1.18 $\mathrm{kg} \mathrm{d}^{-1}$; four: $\left.1.14 \mathrm{~kg} \mathrm{~d}^{-1}\right)$ increased linearly and the feed:gain ratio decreased $(p=0.02)$. Also, as feeding frequency increased, hot carcass weight was affected cubically ( $p=0.01$; one: 246.9 kg; two: $243.0 \mathrm{~kg}$; three: $263.1 \mathrm{~kg}$; four: $258.1 \mathrm{~kg}$ ). During the adaptation period dry matter intake variation was affected cubically ( $p \leq 0.05$; one: $16 \%$; two: $23 \%$; three: $14 \%$; four: $16 \%$ ). Increases in feeding frequency affected papillae height $(p<0.01)$ and papillae surface area $(p<0.01)$ cubically, as well as producing increases in the mitotic index ( $p=0.05$; one: $9 \%$; two: $11 \%$; three: $13 \%$; four: $13 \%$ ) and cells in proliferation $(p=0.05)$ linearly. Thus, Nellore yearling bulls should be fed three times daily in feedlot operations.

Keywords: Zebu, carcass, concentrate, intake, papillae

\section{Introduction}

Nowadays, increasing demand for high-quality beef has led to the necessity for intensification. Consequently, in Brazil, feedlot systems as a method of improving beef quality and reducing age at slaughter have been growing in popularity. Thus changes in management practices are needed since this increase in demand directly affects cattle behavior, health and the cost of production.

To reduce age at slaughter, and accelerate muscle and fat deposition, rations containing high levels of nonfiber carbohydrates, mainly starch, are needed due to the greater nutrient requirements of cattle during the finishing phase. However, when cattle are fed high-grain diets, a broad range of fermentative processes is initiated in the ruminal environment, and if proper feeding management is not in place, a digestive disturbance known as ruminal acidosis may develop (DiLorenzo et al., 2006).

Based on these facts, Millen et al. (2009) reported that there are several nutritional strategies that could be adopted to either avoid or alleviate excessive fermentation of non-fiber carbohydrates in the rumen, such as gradual adaptation to high-grain diets, use of feed additives, larger roughage particles, inclusion of fats in the ration, delivery feed to the bunks at the same time every day, reduction in dry matter intake (DMI) variation, and increases in feeding frequency.

As the literature is not clear about how often feedlot cattle should be fed daily, cattle feeders and nutri- tionists generally determine feeding frequency by considering the number of animals and pens to feed, and the number and capacity of the mixers and equipment available in order to explore maximum performance and reduce problems related to rumen acidification. Robinson and McQueen (1994) reported higher rumen $\mathrm{pH}$ and lesser propionate concentration in the rumen of dairy Holsteins cows fed five times a day when compared to cows fed twice a day. Moreover, Soto-Navarro et al. (2000) reported that feeding steers twice daily decreased ruminal volatile fatty acid concentration and also led to higher ruminal $\mathrm{pH}$ compared to those fed once daily. Robles et al. (2007) fed Holstein heifers once, twice, 3 times, and 4 times daily, and concluded that feeding twice daily could be a practical way to better control the daily fall in $\mathrm{pH}$, and reduce the range of $\mathrm{pH}$ values; however, the ideal feeding frequency for feedlot cattle remains unclear.

Thus, this study was designed to evaluate the effects of different feeding frequencies on feedlot performance, carcass traits, feeding behavior, and rumen morphometrics in Nellore cattle.

\section{Materials and Methods}

This study was conducted in Dracena, São Paulo,

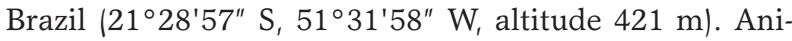
mal care procedures followed guidelines established by the São Paulo State University Ethical Committee for Animal Research (Protocol 37/2012). 


\section{Animals, nutritional management and performance measurements}

Forty-eight 18 month-old bulls with an initial body weight of $358.2 \pm 19.2 \mathrm{~kg}$ were housed in individual pens $(1.0 \mathrm{~m}$ by $7.0 \mathrm{~m})$ and fed ad libitum. The experiment was designed as a completely randomized block and animals were assigned to one offour feeding frequencies evaluated: 1) once daily (at 08:00 [100 \% of total ration]), twice daily (at 08:00 [40\% of total ration] and 14:00 [60 $\%$ of total ration]), three times daily (at 08:00 [30\% of total ration], 11:00 [20\% of total ration] and 14:00 [50\% of total ration]), and four times daily (at 08:00 [25\% of total ration], 11:00 [20\% of total ration], 14:00 [20\% of total ration] and 17:00 [40\% of total ration]). Each treatment was replicated 12 times.

At the beginning of the study in each year, all yearling bulls were dewormed and vaccinated (tetanus, bovine viral diarrhea virus, 7 -way Clostridium sp.). The experiment lasted 94 days: 9 days to adapt cattle to the high-grain diet, and 85 days for the finishing period. The adaptation program consisted of two adaptation diets, which contained $60 \%$ and $73 \%$ concentrate, and spanned a period of 5 and 4 days, respectively. Experimental diets were composed of sugarcane bagasse, coast cross hay, cracked corn grain, soybean meal, soybean hulls and a supplement containing urea (Table 1). The diets were formulated according to the Large Ruminant Nutrition System (LRNS; Fox et al., 2004).

The amount of feed offered was adjusted every day based on the amount of feed refusals (target was 3 $\%$ to $5 \%$ orts) before each morning delivery. Feed offered and refused were weighed daily in the morning

Table 1 - Feed ingredients and chemical composition of experimental diets fed to Nellore yearling bulls consuming high-concentrate diets.

\begin{tabular}{lccc}
\hline \multirow{2}{*}{ Item } & \multicolumn{3}{c}{ Diets } \\
\cline { 2 - 4 } & Adaptation 1 & Adaptation 2 & Finishing \\
\hline Concentrate level (\%) & 60 & 73 & 86 \\
Days on feed & 7 & 7 & 85 \\
Ingredient, \% of DM ${ }^{1}$ & & & \\
Sugarcane bagasse & 27.0 & 21.0 & 14.0 \\
Coast cross hay & 13.0 & 6.0 & - \\
Cracked corn grain & 39.8 & 53.4 & 67.0 \\
Soybean meal & 12.1 & 8.8 & 5.5 \\
Soybean hulls & 5.4 & 7.2 & 9.0 \\
Supplement ${ }^{2}$ & 2.7 & 3.6 & 4.5 \\
Nutrient content, \% of DM & & & \\
DM $^{3}$ & 74.0 & 77.0 & 81.0 \\
TDN $^{3}$ & 72.0 & 76.0 & 78.0 \\
CP $^{4}$ & 14.2 & 14.0 & 14.0 \\
NDF $^{5}$ & 41.4 & 32.7 & 24.0 \\
Ca $^{6}$ & 0.46 & 0.53 & 0.59 \\
P $^{7}$ & 0.29 & 0.30 & 0.31 \\
\hline Dry $^{2}$ & & & \\
\hline
\end{tabular}

1Dry matter; ${ }^{2}$ Supplement contained $27 \%$ of urea as a $\mathrm{N}$ source, as well as $\mathrm{Ca}$, $11 \%$; P, $1 \%$; S, 2 \%; Mg, $1 \%$; Na, 4 \%; Co, $0.001 \%$; Cu, $0.02 \%$; I, $0.001 \%$; Mn, 0.07 \%; Se, 0.0005 \%; Zn, 0.10 \%; Vitamin A, 56430 Ul; Vitamin D, 7054 Ul; Vitamin E, 257 Ul, Monensin Sodium 575 mg.; ${ }^{3}$ Total digestible nutrients; ${ }^{4}$ Crude protein; ${ }^{5}$ Neutral detergent fiber; ${ }^{6}$ Calcium; ${ }^{7}$ Phosphorus. and sampled weekly for chemical analysis. The DMI was calculated daily and expressed in $\mathrm{kg}$ and as a percentage of body weight (BW). Yearling bulls had freechoice water access to a water trough $(0.89 \mathrm{~m} \times 1.00 \mathrm{~m}$ $\times 1.00 \mathrm{~m}$ ). Cattle were not withheld from feed before every BW assessment, carried out both at the beginning and at the end of the study. At each BW assessment, cattle were weighed on two consecutive days and the final data represent the average of the two weights obtained (Stock et al., 1983). Finally, a $4 \%$ discount was applied to the average BW measured to obtain the shrunk BW, which was used to calculate the average daily gain, DMI in $\%$ of BW, and dressing percentage. A fasting period was not used before every BW assessment so as to avoid problems related to aggressive feed consumption on the days following this procedure.

The hot carcass weight was obtained at a commercial abattoir after kidney-pelvic fat removal. Dressing percentage was calculated by dividing hot carcass weight by final BW. Biceps femoris fat thickness (P8) and $12^{\text {th }}$ rib fat thickness were measured via ultrasound at the beginning and at the end of the study following the method described by Perkins et al. (1992). Based on the difference between the initial and the final measurements of fat thickness and the time in days spent on feed, the $12^{\text {th }}$ back fat thickness daily gain and P8 fat thickness daily gain were calculated. Images were collected using a $17.2 \mathrm{~cm}, 3.5 \mathrm{MHz}$ probe. Rib fat thickness was measured at the $12^{\text {th }}$ to $13^{\text {th }}$ rib interface over the Longissimus muscle, two-thirds the distance from the spine between the medial and lateral muscle ends. A single trained technician scanned and analyzed all images. Yearling bulls were all harvested $(n=48)$ when a $12^{\text {th }}$ rib fat thickness of $5 \mathrm{~mm}$ was achieved based upon the average obtained across all treatment groups to achieve the minimum fat cover level that meets Brazilian market requirements. Cattle were transported 150 kilometers $(\sim 3 \mathrm{~h})$ to a commercial abattoir.

\section{Dry matter intake variation}

The DMI variation was calculated using the methodology proposed by Bevans et al. (2005) as the difference in intake between consecutive days throughout the study. Data pertaining to daily DMI variation were expressed both in kilograms and as a percentage of variation as follows: [(DMI current day - DMI previous day) / DMI previous day * 100]. The daily DMI was calculated for both the adapting and finishing periods, as well as for the entire feeding period.

\section{Feeding behavior}

Feeding behavior data were collected visually during the experimental period on day 5 (adaptation period) and day 51 (finishing period) using a method adapted from Robles et al. (2007), whereby feeding behavior was recorded for each animal every 5 min over a $24 \mathrm{~h}$ period. Feeding behavior variables collected were as follows: time spent eating, time spent ruminating and time spent resting expressed in minutes ( $\mathrm{min}$ ) and number of meals per day. 
The DMI were measured on the days data was collected. The meal length in min was calculated by dividing time spent eating by the number of meals per day. The DMI per meal in kg was calculated by dividing DMI by the number of meals per day. Additionally, data pertaining to time spent eating and time spent ruminating were used to calculate the DM eating rate (time spent eating/DMI) and the rumination rate of DM (time spent ruminating/DMI), both expressed in $\min \mathrm{kg}^{-1}$ of $\mathrm{DM}$. Samples of diets and orts were collected for chemical analysis of neutral detergent fiber (NDF, Van Soest et al., 1991) to determine NDF intake on the day of each feeding behavior data collection., and the NDF intake:DMI ratio was calculated to support the data on selective consumption. The NDF eating rate was calculated by dividing time spent eating by the NDF intake. The NDF rumination rate was determined by dividing time spent ruminating by the NDF intake. Both the NDF eating rate and the NDF rumination rate were expressed in min $\mathrm{kg}^{-1}$ of NDF. The eating and rumination rates of both DM and NDF are useful for evaluating how fast cattle consume the feed offered.

\section{Selective consumption}

Samples of diets and orts were also collected on days 5 (adaptation period) and 51 (finishing period) of the study to establish particle-size distribution, which was determined by sieving using a particle size separator and reported on the as-fed basis as described by Kononoff et al. (2003). Selective consumption was determined as follows: $\mathrm{n}$ intake/n predicted intake, in which $\mathrm{n}=$ particle fraction screens of $19 \mathrm{~mm}$ (long), $8 \mathrm{~mm}$ (medium), $1.18 \mathrm{~mm}$ (short), and a pan (fine). Selective consumption values equal to 1 indicate no sorting, < 1 indicate selective refusals (sorting against), and $>1$ preferential consumption (sorting for).

\section{Incidence of rumenitis and liver abscess}

An evaluation of rumenitis was conducted after cattle evisceration, and all entire washed rumens were scored. Rumen epithelium was classified according to the lesion incidences (rumenitis and hyperkeratosis) and abnormalities as described by Bigham and McManus (1975) on a scale of zero to ten, where zero indicated no lesions or abnormalities and ten, severe ulcerative lesions all over the rumen wall. All rumens were scored by two trained individuals, who were blinded to the treatments, and final data represent the average of the two scores. Liver abscesses were scored according to incidence and severity following the method proposed by Brink et al. (1990).

\section{Ruminal morphometrics}

At harvest, rumen and reticulum compartments were isolated. A $1.0 \mathrm{~cm}^{2}$ fragment of each rumen was collected from the cranial sac (Atrium ruminis) and placed into a PBS solution for future morphometric measurements according to Daniel et al. (2006) and Resende
Júnior et al. (2006). Manually, the number of papillae per $\mathrm{cm}^{2}$ of rumen wall (NOP) was determined. Twelve papillae were randomly collected from each fragment, scanned, and mean papillae area (MPA) was determined using an image analysis system. The rumen wall absorptive surface area (ASA) in $\mathrm{cm}^{2}$ was calculated as follows: $1+(\mathrm{NOP} * \mathrm{MPA})-(\mathrm{NOP} * 0.002) ;$ where 1 represents the $1 \mathrm{~cm}^{2}$ fragment collected, and 0.002 is the estimated basal area of papillae in $\mathrm{cm}^{2}$.

Moreover, a $1.0 \mathrm{~cm}^{2}$ fragment of each rumen was collected from the ventral sac for histological and immunohistochemistry assessment. Histological sections were stained with hematoxylin and eosin, embedded in paraffin wax, and sectioned according to Odongo et al. (2006). Morphometric measurements, such as papillae surface area, papillae height, papillae width, keratinized layer thickness, and mitotic index, were determined in four papillae per animal using computer-aided light microscope image analysis. To determine the mitotic index, number of cells exhibiting mitotic figures was determined by using the same microscope just described, and final data was expressed as a percentage of two thousand cells.

Immunohistochemistry variables were evaluated using a technique adapted from Pereira et al. (2010) to determine cell proliferation and cell death indexes of the rumen epithelium. The same $1.0 \mathrm{~cm}^{2}$ fragment collected from the ventral sac was used. The number of dead cells and proliferating cells was determined in 4 papillae per animal using TUNEL and PCNA immunohistochemistry techniques, respectively. The same microscope just described was used and data were expressed as a percentage of all cells in each papillae. The final data represent the average of the four indexes calculated.

\section{Statistical analysis}

All data collected in this study were analyzed as a completely randomized block design using the MIXED procedure of SAS (Statistical Analysis System, v. 9.2) including the CONTRAST option. The model included the main effect of feeding frequency (one, two, three, or four times daily), and the random effect of block. Initial BW was used as criteria to form the 12 blocks utilized in this study. Orthogonal contrasts were used to assess linear, quadratic and cubic relationship between feeding frequency and the dependent variable. Results were considered significant at $p \leq 0.05$ level.

\section{Results}

\section{Feedlot performance and carcass traits}

Results on feedlot performance and carcass traits are presented in Table 2 . As feeding frequency increased, final BW ( $p \leq 0.03$ ) and average daily gain (ADG; $p \leq$ 0.01 ) increased linearly. Furthermore, as feeding frequency increased, the G:F ratio increased $(p \leq 0.02)$ and, as feeding frequency increased, hot carcass weight was affected cubically $(p \leq 0.01)$. On the other hand, feed- 
ing frequency did not affect $(p>0.05)$ the other performance and carcass trait variables evaluated in this study (Table 2).

\section{Dry matter intake variation}

Results of DMI variation are presented in Table 3. During the adaptation period, as feeding frequency increased, DMI variation, expressed both in percentage and kilograms, was affected cubically ( $p \leq 0.05)$. However, as feeding frequency increased DMI variation expressed in kilograms was affected quadratically during the finishing period $(p \leq 0.03)$ as well as during the entire feeding period $(p \leq 0.02 \mathrm{~kg})$. The DMI variation expressed in percentage remained unaffected $(p>0.05)$ during both the finishing and entire feeding periods (Table 3).

\section{Feeding behavior and selective consumption}

Feeding behavior results are presented in Table 4 . As feeding frequency increased, during the adaptation period, NDF intake was affected cubically $(p \leq 0.02)$ and NDF intake:DMI ratio was affected quadratically $(p \leq$ $0.01)$. On the other hand, for the adaptation period, feeding frequency did not affect $(p>0.05)$ DMI, time spent eating, time spent ruminating, time spent resting, meals per day, DMI per meal, meal length, eating rate of DM, rumination rate of DM, eating rate of NDF and rumination rate of NDF (Table 4).

Moreover, during the finishing period, as feeding frequency increased, DMI $(p \leq 0.02)$ inceased linearly, time spent ruminating $(p \leq 0.01)$ and time spent resting $(p \leq 0.01)$ were affected cubically, and NDF intake

Table 2 - Performance and carcass traits of Nellore feedlot cattle subjected to different feeding frequencies.

\begin{tabular}{|c|c|c|c|c|c|c|c|c|}
\hline \multirow{2}{*}{ Item } & \multicolumn{4}{|c|}{ Feeding frequency ${ }^{1}$} & \multirow{2}{*}{$\mathrm{SEM}^{2}$} & \multicolumn{3}{|c|}{ Probability ( $p$ value) } \\
\hline & $1 x$ & $2 x$ & $3 x$ & $4 x$ & & Linear & Quadratic & Cubic \\
\hline \multicolumn{9}{|l|}{ Feedlot performance } \\
\hline Initial $\mathrm{BW}^{3}, \mathrm{~kg}$ & 356.79 & 355.63 & 356.92 & 357.19 & 7.89 & 0.70 & 0.62 & 0.59 \\
\hline Final BW, kg & 449.81 & 445.43 & 467.43 & 463.61 & 9.51 & 0.03 & 0.96 & 0.07 \\
\hline $\mathrm{ADG}^{4}, \mathrm{~kg} \mathrm{~d}^{-1}$ & 0.979 & 0.961 & 1.175 & 1.138 & 0.060 & 0.01 & 0.87 & 0.08 \\
\hline $\mathrm{DMl}^{5}, \mathrm{~kg} \mathrm{~d}^{-1}$ & 7.75 & 7.95 & 8.44 & 8.10 & 0.24 & 0.12 & 0.22 & 0.26 \\
\hline DMI, $\%$ of BW & 1.91 & 1.98 & 2.04 & 1.97 & 0.04 & 0.25 & 0.09 & 0.55 \\
\hline Gain:feed ratio & 0.128 & 0.121 & 0.141 & 0.142 & 0.006 & 0.02 & 0.52 & 0.08 \\
\hline \multicolumn{9}{|l|}{ Carcass traits } \\
\hline $\mathrm{HCW}^{6}, \mathrm{~kg}$ & 246.91 & 242.99 & 263.07 & 258.05 & 5.98 & 0.01 & 0.89 & 0.01 \\
\hline Dressing percentage & 54.97 & 54.62 & 56.14 & 55.58 & 0.51 & 0.15 & 0.84 & 0.09 \\
\hline Kidney-pelvic fat, kg & 3.42 & 3.43 & 3.73 & 3.98 & 0.34 & 0.18 & 0.71 & 0.82 \\
\hline Kidney-pelvic fat, $\%$ of HCW & 1.38 & 1.40 & 1.41 & 1.53 & 0.12 & 0.37 & 0.68 & 0.80 \\
\hline Initial $12^{\text {th }}$ back fat thickness, $\mathrm{mm}$ & 2.38 & 2.36 & 2.45 & 2.47 & 0.10 & 0.41 & 0.84 & 0.68 \\
\hline Final $12^{\text {th }}$ back fat thickness, $\mathrm{mm}$ & 5.53 & 5.58 & 5.41 & 5.86 & 0.26 & 0.48 & 0.44 & 0.47 \\
\hline $12^{\text {th }}$ back fat thickness daily gain, $\mathrm{mm} \mathrm{d}^{-1}$ & 0.034 & 0.035 & 0.032 & 0.037 & 0.003 & 0.68 & 0.48 & 0.37 \\
\hline Initial P8 fat thickness, mm & 2.78 & 2.52 & 2.79 & 2.64 & 0.12 & 0.75 & 0.61 & 0.07 \\
\hline Final P8 fat thickness, mm & 6.24 & 6.37 & 6.31 & 6.50 & 0.28 & 0.57 & 0.92 & 0.73 \\
\hline P8 fat thickness daily gain, $\mathrm{mm} \mathrm{d}^{-1}$ & 0.038 & 0.042 & 0.038 & 0.042 & 0.003 & 0.44 & 0.91 & 0.23 \\
\hline
\end{tabular}

${ }^{1} 1 \times(08 \mathrm{~h} 00$ [100 \% of total ration]), $2 \times(08 \mathrm{~h} 00$ [40 \% of total ration] and $14 \mathrm{~h} 00$ [60 \% of total ration]), 3x (08h00 [30 \% of total ration], $11 \mathrm{~h} 00$ [20\% of total ration] and $14 \mathrm{~h} 00$ [50 \% of total ration]), and $4 \times(08 \mathrm{~h} 00$ [25 \% of total ration], $11 \mathrm{~h} 00$ [20\% of total ration], $14 \mathrm{~h} 00$ [20 \% of total ration] and $17 \mathrm{~h} 00$ [40 \% of total ration]); ${ }^{2}$ Standard error of mean; ${ }^{3}$ Body weight; ${ }^{4}$ Average daily gain; ${ }^{5}$ Dry matter intake; ${ }^{6} \mathrm{Hot}$ carcass weight.

Table 3 - Dry matter intake variation of in kilograms and percentage of Nellore feedlot cattle subjected to different feeding frequencies during the adaptation period, finishing period and entire feeding period.

\begin{tabular}{|c|c|c|c|c|c|c|c|c|}
\hline \multirow{2}{*}{ Item } & \multicolumn{4}{|c|}{ Feeding frequency ${ }^{1}$} & \multirow{2}{*}{$\mathrm{SEM}^{2}$} & \multicolumn{3}{|c|}{ Probability ( $p$ value) } \\
\hline & $1 x$ & $2 x$ & $3 x$ & $4 x$ & & Linear & Quadratic & Cubic \\
\hline \multicolumn{9}{|c|}{ Adaptation period (14 days) } \\
\hline $\mathrm{DMI}^{3}$ variation, $\%$ & 16.06 & 23.17 & 14.41 & 15.89 & 2.86 & 0.47 & 0.33 & 0.05 \\
\hline DMI variation, $\mathrm{kg}$ & 0.82 & 1.07 & 0.80 & 0.84 & 0.09 & 0.63 & 0.27 & 0.05 \\
\hline \multicolumn{9}{|c|}{ Finishing period (80 days) } \\
\hline DMI variation, \% & 15.64 & 15.94 & 17.51 & 16.35 & 1.38 & 0.55 & 0.60 & 0.53 \\
\hline DMl variation, $\mathrm{kg}$ & 0.97 & 1.06 & 1.28 & 1.12 & 0.05 & 0.01 & 0.03 & 0.37 \\
\hline \multicolumn{9}{|c|}{ Entire feeding period (94 days) } \\
\hline DMI variation, \% & 15.69 & 16.85 & 17.18 & 16.30 & 1.31 & 0.71 & 0.44 & 0.95 \\
\hline DMI variation, $\mathrm{kg}$ & 0.95 & 1.06 & 1.23 & 1.09 & 0.05 & 0.01 & 0.02 & 0.10 \\
\hline
\end{tabular}

${ }^{1} 1 \times(08 \mathrm{~h} 00$ [100 \% of total ration]), $2 \times$ (08h00 [40 \% of total ration] and $14 \mathrm{~h} 00$ [60 \% of total ration]), 3x (08h00 [30\% of total ration], $11 \mathrm{~h} 00$ [20\% of total ration] and $14 \mathrm{~h} 00$ [50 \% of total ration]), and $4 x$ (08h00 [25\% of total ration], $11 \mathrm{~h} 00$ [20\% of total ration], $14 \mathrm{~h} 00$ [20 \% of total ration] and $17 \mathrm{~h} 00$ [40 \% of total ration]); ${ }^{2}$ Standard error of mean, ${ }^{3}$ Dry matter intake. 
Table 4 - Feeding behavior variables of Nellore feedlot cattle subjected to different feeding frequencies during the adaptation and the finishing periods.

\begin{tabular}{|c|c|c|c|c|c|c|c|c|}
\hline \multirow{2}{*}{ Item } & \multicolumn{4}{|c|}{ Feeding frequency ${ }^{1}$} & \multirow{2}{*}{$\mathrm{SEM}^{2}$} & \multicolumn{3}{|c|}{ Probability ( $p$ value) } \\
\hline & $1 x$ & $2 x$ & $3 x$ & $4 x$ & & Linear & Quadratic & Cubic \\
\hline \multicolumn{9}{|l|}{ Adaptation period } \\
\hline $\mathrm{DM}^{3}, \mathrm{~kg}$ & 6.77 & 7.33 & 7.63 & 6.52 & 0.43 & 0.82 & 0.06 & 0.55 \\
\hline Time spent eating, min & 172.92 & 185.00 & 164.58 & 152.92 & 14.18 & 0.16 & 0.45 & 0.62 \\
\hline Time spent ruminating, min & 217.92 & 191.67 & 190.83 & 189.58 & 17.76 & 0.29 & 0.49 & 0.75 \\
\hline Time spent resting, min & 1049.17 & 1063.33 & 1084.58 & 1097.50 & 22.50 & 0.11 & 0.98 & 0.88 \\
\hline Meals per day, $\mathrm{n}$ & 13.50 & 16.67 & 14.42 & 13.08 & 1.24 & 0.60 & 0.14 & 0.35 \\
\hline DMl per meal, kg & 0.54 & 0.51 & 0.57 & 0.49 & 0.06 & 0.82 & 0.66 & 0.38 \\
\hline Meal length, min & 12.43 & 11.27 & 12.03 & 12.17 & 0.91 & 1.00 & 0.48 & 0.54 \\
\hline Eating rate of $\mathrm{DM}^{4}, \min \mathrm{kg}^{-1}$ & 25.51 & 23.66 & 21.02 & 22.95 & 2.04 & 0.23 & 0.41 & 0.65 \\
\hline Rumination rate of $\mathrm{DM}, \mathrm{min} \mathrm{kg}^{-1}$ & 28.95 & 26.57 & 24.89 & 31.45 & 2.57 & 0.70 & 0.12 & 0.43 \\
\hline NDF$^{5}$ intake, $\mathrm{kg}$ & 2.03 & 1.80 & 2.08 & 1.74 & 0.10 & 0.22 & 0.60 & 0.02 \\
\hline NDF intake: DMI ratio & 0.29 & 0.25 & 0.27 & 0.27 & 0.01 & 0.29 & $<0.01$ & 0.12 \\
\hline Eating rate of NDF, min $\mathrm{kg}^{-1}$ & 88.55 & 83.36 & 80.75 & 86.14 & 6.43 & 0.73 & 0.41 & 0.85 \\
\hline Rumination rate of NDF, min $\mathrm{kg}^{-1}$ & 103.81 & 108.00 & 91.20 & 116.14 & 7.36 & 0.71 & 0.31 & 0.09 \\
\hline \multicolumn{9}{|l|}{ Finishing period } \\
\hline DMl, kg & 8.34 & 8.69 & 9.59 & 9.15 & 0.36 & 0.02 & 0.22 & 0.19 \\
\hline Time spent eating, min & 175.42 & 177.08 & 204.58 & 179.58 & 14.34 & 0.51 & 0.33 & 0.20 \\
\hline Time spent ruminating, min & 427.08 & 385.83 & 455.83 & 429.17 & 15.14 & 0.27 & 0.63 & $<0.01$ \\
\hline Time spent resting, min & 837.50 & 877.08 & 779.58 & 831.25 & 20.25 & 0.19 & 0.76 & $<0.01$ \\
\hline Meals per day, $\mathrm{n}$ & 13.33 & 14.58 & 15.67 & 13.25 & 1.24 & 0.88 & 0.15 & 0.55 \\
\hline DMI per meal, kg & 0.67 & 0.70 & 0.64 & 0.72 & 0.05 & 0.75 & 0.68 & 0.45 \\
\hline Meal length, min & 13.53 & 12.81 & 13.50 & 13.74 & 0.80 & 0.72 & 0.55 & 0.60 \\
\hline Eating rate of $\mathrm{DM}, \min \mathrm{kg}^{-1}$ & 20.91 & 20.50 & 21.45 & 19.78 & 1.49 & 0.71 & 0.67 & 0.54 \\
\hline Rumination rate of $\mathrm{DM}$, min $\mathrm{kg}^{-1}$ & 51.76 & 44.68 & 47.98 & 48.07 & 2.19 & 0.40 & 0.09 & 0.14 \\
\hline NDF intake, kg & 2.58 & 4.08 & 3.45 & 2.80 & 0.14 & 0.93 & $<0.01$ & $<0.01$ \\
\hline NDF intake: DMI ratio & 0.31 & 0.47 & 0.36 & 0.31 & 0.01 & $<0.01$ & $<0.01$ & 0.11 \\
\hline Eating rate of NDF, $\min \mathrm{kg}^{-1}$ & 68.15 & 43.94 & 59.68 & 64.96 & 4.33 & 0.74 & $<0.01$ & $<0.01$ \\
\hline Rumination rate of NDF, min $\mathrm{kg}^{-1}$ & 168.55 & 95.13 & 133.84 & 157.41 & 7.36 & 0.86 & $<0.01$ & $<0.01$ \\
\hline
\end{tabular}

${ }^{1} 1 \mathrm{x}(08 \mathrm{~h} 00$ [100 \% of total ration]), $2 x$ (08h00 [40 \% of total ration] and $14 \mathrm{~h} 00$ [60 \% of total ration]), 3x (08h00 [30 \% of total ration], $11 \mathrm{~h} 00$ [20\% of total ration] and $14 \mathrm{~h} 00$ [50\% of total ration]), and $4 \times(08 \mathrm{~h} 00$ [25\% of total ration], $11 \mathrm{~h} 00$ [20\% of total ration], $14 \mathrm{~h} 00$ [20\% of total ration] and $17 \mathrm{~h} 00$ [40\% of total ration]); ${ }^{2}$ Standard error of mean; ${ }^{3}$ Dry matter intake; ${ }^{4}$ Dry matter; ${ }^{5}$ Neutral detergent fiber.

$(p \leq 0.01)$, the NDF intake:DMI ratio $(p \leq 0.01)$, the NDF eating $(p \leq 0.01)$ and the NDF rumination rate $(p \leq 0.01)$ were affected quadratically. On the other hand, feeding frequency did not affect $(p>0.05)$ time spent eating, meals per day, DMI per meal, meal length, eating rate of DM and rumination rate of DM during this period (Table 4).

Selective consumption results are presented in Table 5. As feeding frequency increased, the $1.18 \mathrm{~mm}$ screen was affected quadratically $(p \leq 0.02)$ during the adaptation period. However, no feeding frequency effect $(p>0.05)$ was observed for any other variable measured in this study related to selective consumption (Table 5).

\section{Liver abscess, incidence of rumenitis and ruminal morphometrics}

Liver abscesses were not observed in any of the animals. Feeding frequency did not affect $(p>0.05)$ the incidence of rumenitis in the animals studied (Table 6).

Feeding frequency did not affect $(p>0.05)$ the ruminal morphometrics parameters measured in the cranial sac, such as the number of papillae, mean papillae area, absorptive surface area, and papillae area expressed as a percentage of the absorptive surface area. Also, feeding frequency did not affect $(p>0.05)$ papillae width, keratinized layer thickness, proliferation index, number of dead cells, and the cell death index measured in the ventral sac. However, as feeding frequency increased, papillae height $(p \leq 0.01)$ and papillae surface area $(p \leq 0.01)$ measured in the ventral sac were affected cubically. In addition, as feeding frequency increased, cells in mitosis $(p \leq 0.05)$, the mitotic index $(p \leq 0.05)$ and cells in proliferation $(p \leq 0.05)$, also measured in the ventral sac, increased linearly (Table 6).

\section{Discussion}

Usually where there are increases in feeding frequency, an increase in DMI would also be expected which would, in turn, increase ADG and the final BW. Despite the linear increase observed $(p \leq 0.05)$ for ADG and the final BW, this effect was not observed $(p>0.05)$ 
Table 5 - Selective consumption related of the diets offered to Nellore cattle submitted to different feeding frequencies during the adaptation and the finishing period.

\begin{tabular}{|c|c|c|c|c|c|c|c|c|}
\hline \multirow{2}{*}{ Item $^{3}$} & \multicolumn{4}{|c|}{ Feeding frequency ${ }^{1}$} & \multirow{2}{*}{ SEM $^{2}$} & \multicolumn{3}{|c|}{ Probability ( $p$ value) } \\
\hline & $1 x$ & $2 x$ & $3 x$ & $4 x$ & & Linear & Quadratic & Cubic \\
\hline \multicolumn{9}{|l|}{ Adaptation period } \\
\hline 19.0 mm screen & 1.184 & 1.039 & 1.121 & 1.122 & 0.111 & 0.87 & 0.55 & 0.48 \\
\hline 8.0 mm screen & 1.010 & 1.003 & 0.998 & 1.006 & 0.032 & 0.95 & 0.85 & 0.90 \\
\hline 1.18 mm screen & 0.993 & 0.996 & 0.999 & 0.986 & 0.003 & 0.35 & 0.02 & 0.07 \\
\hline Pan & 1.023 & 1.005 & 1.001 & 1.021 & 0.013 & 0.86 & 0.14 & 0.84 \\
\hline \multicolumn{9}{|l|}{ Finishing period } \\
\hline 19.0 mm screen & 1.024 & 0.907 & 0.925 & 0.943 & 0.039 & 0.18 & 0.08 & 0.43 \\
\hline 8.0 mm screen & 0.948 & 0.945 & 0.951 & 0.940 & 0.017 & 0.79 & 0.81 & 0.69 \\
\hline 1.18 mm screen & 0.981 & 0.980 & 0.983 & 0.983 & 0.005 & 0.63 & 0.89 & 0.75 \\
\hline Pan & 1.067 & 1.097 & 1.077 & 1.084 & 0.019 & 0.74 & 0.55 & 0.36 \\
\hline
\end{tabular}

Table 6 - Incidence of rumenitis and rumen morphometrics of feedlot Nellore cattle submitted to different feeding frequencies.

\begin{tabular}{|c|c|c|c|c|c|c|c|c|}
\hline \multirow{2}{*}{ Item } & \multicolumn{4}{|c|}{ Feeding frequency ${ }^{1}$} & \multirow{2}{*}{$\mathrm{SEM}^{2}$} & \multicolumn{3}{|c|}{ Probability ( $p$ value) } \\
\hline & $1 x$ & $2 x$ & $3 x$ & $4 x$ & & Linear & Quadratic & Cubic \\
\hline Rumenitis score & 2.00 & 1.80 & 2.20 & 2.30 & 0.42 & 0.49 & 0.72 & 0.63 \\
\hline \multicolumn{9}{|l|}{ Cranial sac } \\
\hline Number of papillae, $n$ & 45.00 & 43.00 & 40.00 & 42.00 & 3.16 & 0.42 & 0.50 & 0.51 \\
\hline Mean papillae area, $\mathrm{cm}^{2}$ & 0.52 & 0.49 & 0.47 & 0.56 & 0.05 & 0.67 & 0.19 & 0.62 \\
\hline Rumen wall absorptive surface area, $\mathrm{cm}^{2}$ & 23.09 & 21.64 & 20.17 & 24.61 & 2.32 & 0.77 & 0.21 & 0.57 \\
\hline Papillae area, $\%$ of absorptive surface area & 95.68 & 95.11 & 94.67 & 95.91 & 0.58 & 0.92 & 0.13 & 0.55 \\
\hline \multicolumn{9}{|l|}{ Ventral sac } \\
\hline Papillae height, mm & 2.85 & 2.79 & 3.29 & 3.14 & 0.06 & $<0.01$ & 0.50 & $<0.01$ \\
\hline Papillae width, mm & 0.37 & 0.36 & 0.34 & 0.35 & 0.01 & 0.07 & 0.21 & 0.44 \\
\hline Papillae area, $\mathrm{mm}^{2}$ & 1.11 & 1.11 & 1.29 & 1.22 & 0.03 & $<0.01$ & 0.25 & $<0.01$ \\
\hline Keratinized layer thickness, $\mu \mathrm{m}$ & 20.26 & 19.48 & 20.37 & 20.85 & 0.57 & 0.30 & 0.27 & 0.42 \\
\hline Cells in mitosis, $n$ & 182.33 & 211.92 & 257.00 & 252.67 & 28.08 & 0.05 & 0.55 & 0.61 \\
\hline Mitotic index, $\%$ of basal cells & 9.12 & 10.60 & 12.85 & 12.63 & 1.40 & 0.05 & 0.55 & 0.61 \\
\hline Cells in proliferation, $n$ & 536.71 & 799.01 & 854.07 & 830.82 & 106.92 & 0.04 & 0.20 & 0.81 \\
\hline Proliferation index, \% & 71.78 & 70.15 & 68.69 & 70.67 & 1.77 & 0.55 & 0.31 & 0.68 \\
\hline Number of dead cells, $n$ & 692.57 & 770.90 & 813.41 & 760.82 & 136.64 & 0.69 & 0.63 & 0.92 \\
\hline Cell death index, \% & 67.85 & 69.07 & 66.58 & 68.44 & 1.66 & 0.91 & 0.84 & 0.28 \\
\hline
\end{tabular}

${ }^{1} 1 \mathrm{x}(08 \mathrm{~h} 00$ [100 \% of total ration]), $2 \mathrm{x}(08 \mathrm{~h} 00$ [40 \% of total ration] and $14 \mathrm{~h} 00$ [60 \% of total ration]), 3x (08h00 [30\% of total ration], $11 \mathrm{~h} 00$ [20\% of total ration] and $14 \mathrm{~h} 00$ [50\% of total ration]), and $4 x(08 \mathrm{~h} 00$ [25\% of total ration], $11 \mathrm{~h} 00$ [20\% of total ration], $14 \mathrm{~h} 00$ [20\% of total ration] and $17 \mathrm{~h} 00$ [40 \% of total ration]); ${ }^{2}$ Standard error of mean.

for DMI in this study. Nonetheless, it seems that cattle fed either three or four times daily had more stable fermentation, as they presented a greater number of proliferating cells in the rumen epithelium, which resulted in a higher mitotic index and larger papillae areain the ventral sac, which may explain the linear increase in ADG and the final BW. Based on this fact, the G:F ratio improved linearly, $(p \leq 0.05)$, which shows that the greater the feeding frequency, the more efficient the consumption by cattle leading, in turn, to better feedlot performance. Moreover, the cubic response obtained for HCW indicates that Nellore yearling bulls fed three times a day were even more efficient in converting feed into carcass components when compared to cattle fed once, twice, or four times a day. These results agree with Colemen and Wyatt (1982) and Sniffen and Robinson (1984) who stated that increases in ADG and improvements in feed efficiency are often observed with increases in feeding frequency, and this might be related to the greater uniformity in rumen metabolites. Furthermore, Schwartzkopf-Genswein et al. (2011) reported higher ADG and an improved G:F ratio for cattle that had more meals per day, ranging from 4.0 to 6.6 times. In this study, DMI and ADG were lower than the values usually documented in the literature for two main reasons: cattle were fed in individual pens, which may have 
reduced DMI; moreover; they had a considerable rate of adipose tissue accretion on carcass during the study, which increased their maintenance requirements, and negatively impacted DMI, resulting in low ADG.

The fact that cattle fed three times daily showed less DMI variation during the adaptation period might have contributed to promoting a better rumen environment for fermentation, and as a result, improvements in the G:F ratio. Yang and Varga (1989) reported that DMI variation decreases as feeding frequency increases, which may lead to more stable ruminal conditions. Although the adaptation period represents only a small portion of the entire feeding period (no more than $20 \%$ according to Brown et al., 2006), it is a critical period because the rumen epithelium is still developing to adjust for the production and absorption of short-chain fatty acids. Cattle fed three times daily presented the largest papillae area in this study, which may be a positive effect of more adequate rumen fermentation during the adaptation period. However, in the finishing period, cattle fed three times daily had increased DMI variation in $\mathrm{kg}$, but not in percentage terms, which was not enough to negatively affect feedlot performance and rumen morphometrics of these animals, possibly because they were already well adapted to the finishing diet fed. Galyean et al. (1992) showed that daily DMI variation greater than $10 \%$ may negatively impact cattle performance, but in their study cattle were fed in groups, not in individual pens as in this study.

Cattle fed once and three times daily presented greater NDF intake during the adaptation period, which may have contributed to less DMI variation when cattle was fed three times a day. Similarly, cattle fed twice a day consumed less NDF than expected during adaptation, as indicated by the NDF intake:DMI data ratio, which is important for rumen buffering and may have compromised the development of papillae, in terms of height and area, in the ventral sac. In addition, in the finishing period, cattle fed twice daily sorted for NDF, which may have impaired the feedlot performance of these animals. Cattle fed three times daily spent more time ruminating in the finishing period, possibly due to the numerical increase in number of meals per day, which may have in part contributed to more stable rumen fermentation resulting in an improved G:F ratio and heavier HCW. Deswysen et al. (1993) concluded that the time, feeding frequency and interval between meals could affect the distribution of feeding activities (as intake, rumination and resting) during the day. Based on this, feeding cattle three times daily seems to better adequate feeding activities during the day. Animals fed only once a day had lower NDF eating and rumination rates in the finishing period, which may have negatively impacted DMI and, consequently, the overall feedlot performance of these animals. Furthermore, the animals fed once a day also presented the lowest papillae growth, once the papillae height, papillae surface area, cells in mitosis, mitotic index and cells in proliferation had presented a decreased linear effect
( $p \leq 0.05)$. This might occur when cattle are challenged with a great amount of feed only once a day, which disturbs the animals' capacity of controlling intake at the beginning of the adaptation period to prevent acidosis and avoid high ruminal variation in $\mathrm{pH}$. Therefore, cattle fed once a day in this study may have learnt to control intake only after the adaptation period, leaving them not well adapted to the final diet, which may have impaired their performance. Soto-Navarro et al. (2000) reported a decrease of propionate production in animals fed once when compared to those fed twice a day, consequently reducing papillae growth. In addition, cattle fed twice a day presented lower NDF intake during the adaptation period and, thus, had less fiber to stimulate rumination and rumen buffering, which might have decreased microbial yield and short-chain fatty acid production, resulting in less rumen epithelium development and poorer performance when compared to cattle fed three or four times.

The use of nutritional management to reduce DMI variation during the adaptation period, as in the case of cattle fed three times a day, is an important decision that should be taken into account in a feedlot system because it positively impacted rumen epithelium capacity for short-chain fatty acid removal, and as a result, improved cattle performance. Thus, it was concluded that Nellore yearling bulls should be fed three times daily in feedlot operations.

\section{Acknowledgements}

We would like to thank São Paulo Research Foundation (FAPESP) for financially supporting this project (Grant number: 2012/02069-5).

\section{References}

Bevans, D.W.; Beauchemin, K.A.; Schwartzkopf-Genswein, K.S.; McKinnon, J.J.; McAllister, T.A. 2005. Effect of rapid or gradual grain adaptation on subacute acidosis and feed intake by feedlot cattle. Journal of Animal Science 83: 1116-1132.

Bigham, M.L.; McManus, W.R. 1975. Whole wheat grain feeding of lambs. Effects of roughage and wheat grain mixtures. Australian Journal of Agricultural Research 26: 1053-1062.

Brink, D.R.; Lowry, S.R.; Stock, R.A.; Parrot, J.C. 1990. Severity of liver abscesses and efficiency of feed utilization of feedlot cattle. Journal of Animal Science 68: 1201-1207.

Brown, M.S.; Ponce, C.H.; Pulikani, R. 2006. Adaptation of beef cattle to high concentrate diets: Performance and ruminal metabolism. Journal of Animal Science 84: 25-33.

Coleman, S.W.; Wyatt, R.D. 1982. Cottonseed meal or small grains forages as protein supplements fed at different intervals. Journal of Animal Science 55: 11-17.

Daniel, J.L.P.; Resende Júnior, J.C.; Cruz, F.J. 2006. Participation of the reticulorumen and omasum in the total absorptive surface of the bovine forestomach $=$ Participação do ruminoretículo e omaso na superfície absortiva total do proventrículo de bovinos. Brazilian Journal of Veterinary Research and Animal Science 43: 688-694 (in Portuguese). 
Deswysen, A.G.; Dutilleul, P.; Godfrin, J.P.; Ellis, W.C. 1993. Nycterohemeral eating and ruminating patterns in heifers fed grass or corn silages: analysis by finite Fourier transform. Journal of Animal Science 71: 2739-2747.

DiLorenzo, N.; Diez-Gonzalez, F.; DiCostanzo, A. 2006. Effects of feeding polyclonal antibody preparations on rumen bacterial populations and ruminal $\mathrm{pH}$ of steers fed high grain diets. Journal of Animal Science 84: 2178-2185.

Fox, D.G.; Tedeschi, L.O.; Tylutki, T.P.; Russell, J.B.; Van Amburgh, M.E.; Chase, L.E.; Pell, A.N.; Overton, T.R. 2004. The cornell net carbohydrate and protein system model for evaluating herd nutrition and nutrient excretion. Animal Feed Science and Technology 112: 29-78.

Galyean, M.L.; Malcolm, K.F.; Duff, G.C. 1992. Performance of feedlot steers fed diets containing laidlomycin propionate or monensin plus tylosin, and effects of laidlomycin propionate concentration on intake patterns and ruminal fermentation in beef steers during adaptation to a high concentrate diet. Journal of Animal Science 70: 2950-2958.

Kononoff, P.J.; Heinrichs, A.J.; Buckmaster, D.R. 2003. Modification of the Penn State forage and total mixed ration particle separator and the effects of moisture content on its measurements. Journal Dairy Science 86: 1858-1863.

Millen, D.D.; Pacheco, R.D.L.; Arrigoni, M.D.B.; Galyean, M.L.; Vasconcelos, J.T. 2009. A snapshot of management practices and nutritional recommendations used by feedlot nutritionists in Brazil. Journal of Animal Science 87: 3427-3439.

Odongo, N.E.; Alzahal, O.; Lindinger; M.I.; Duffield, T.F.; Valdez, E.V.; Terrell, S.P.; McBride, B.W. 2006. Effects of mild heat stress and grain challenge on acid-base balance and rumen tissue histology in lambs. Journal of Animal Science 84: 447455.

Pereira, F.T.; Braga, F.C.; Burioli, K.C.; Kafoury, J.R.; Oliveira, L.J.; Papa, P.C.; Carvalho, A.F.; Ambrósio, C.E.; Bazer, F.W.; Miglino, M.A. 2010. Transplacental transfer of iron in the water buffalo (Bubalus bubalis): uteroferrin and Erythrophagocytosis. Reproduction in Domestic Animals 45: 907-914.

Perkins, T.L.; Green, R.D.; Hamlin, K.E. 1992. Evaluation of ultrasonic estimates of carcass fat thickness and longissimus muscle area in beef cattle. Journal Animal Science 70: 10021010 .
Resende Júnior, J.C.; Alonso, L.S.; Pereira, M.N.; Magallanes, M.G.R.; Duboc, M.V.; Oliveira, E.C.; Melo, L.Q. 2006. Effect of the feeding pattern on rumen wall morphology of cows and sheep. Brazilian Journal of Veterinary Research and Animal Science 43: 526-536.

Robinson, P.H.; McQueen, R.E. 1994. Influence of supplemental protein source and feeding frequency on rumen fermentation and performance in dairy cows. Journal of Dairy Science 77: 1340-1353.

Robles, V.; González, L.A.; Ferret, A.; Manteca, X.; Calsamiglia, S. 2007. Effects of feeding frequency on intake, ruminal fermentation, and feeding behavior in heifers fed highconcentrate diets. Journal of Animal Science 85: 2538-2547.

Schwartzkopf-Genswein, K.S.; Beauchemin, K.A.; Shah, M.A. 2011. Relationship between feeding behavior and performance of feedlot steers fed barley-based diets. Journal of Animal Science 89: 1180-1192.

Sniffen, C.J.; Robinson, P.H. 1984. Nutritional strategy. Journal of Animal Science 64: 529-542.

Soto-Navarro, S.A.; Krehbiel, C.R.; Duff, G.C.; Galyean, M.L.; Brown, M.S.; Steiner, R.L. 2000. Influence of feed intake fluctuation and frequency of feeding on nutrient of digestion, digesta kinetics, and ruminal fermentation profiles in limit-fed steers. Journal of Animal Science 78: 2215-2222.

Stock, R.; Klopfenstein, T.; Brink, D.; Lowry, S.; Rock, D.; Abrams, S. 1983. Impact of weighing procedures and variation in protein degradation rate on measured performance of growing lambs and cattle. Journal of Animal Science 57: 12761285.

Van Soest, P.J.; Robertson, J.B.; Lewis, B.A. 1991. Symposium: carbohydrate methodology, metabolism, and nutritional implications in dairy cattle. Methods for dietary fiber, neutral detergent fiber, and non-starch polysaccharides in relation to animal nutrition. Journal of Animal Science 74: 3583-3597.

Yang, C.M.J.; Varga, G.A. 1989. Effect of three concentrate feeding frequencies on rumen protozoa, rumen digesta kinetics, and milk yield in dairy cows. Journal of Dairy Science 72: 950-957. 